\title{
Pertumbuhan Bibit Salak [Salacca zalacca (Gaertner) Voss] Pondoh yang Diinokulasi dengan Isolat Bakteri Potensial di Tanah Regosol Darmaga
}

\author{
Fahrizal Hazra \\ Diterima 8 Desember 2014/Disetujui 2 Maret 2015
}

\begin{abstract}
Snake fruit [Salacca zalacca (Gaertner) Voss] Pondoh is one of important fruits in Indonesia. The objective of the study was to determine the influence of some selected potential microbes such as Phosphate Solubilizing Bacteria, Cellulolytic Bacteria, and N2-fixing Bacteria (Azospirillum) on growth of seedling of snake fruit Pondoh. A study was conducted in the nursery. The experiment used a completely randomized design with treatments namely: KO (without inoculum); AI (Azospirillum inoculum dose $5 \mathrm{ml}$ ), A2 (inoculum $25 \mathrm{ml}$ ); F1 (BPF inoculum dose $5 \mathrm{ml}$ ), F2 (dose 25 $\mathrm{ml}$ ); $S 1$; BPS inoculums (dose $5 \mathrm{ml}$ ), $S 2$ (dose $25 \mathrm{ml}$ ); $C 1$ (mixed bacterial inoculum $A+F+S$ dose 5 $\mathrm{ml})$, and $C 2(A+F+S$ dose $25 \mathrm{ml})$. Plant height, $P, C / N$ soil ratio, $N$ were measured in 10 months for observing the impact of treatments. Results showed that the effect of inoculation of $A 2$ to the amount of $\mathrm{N}$-total (0.99\%) was significantly different compared to soil with KO; and not significantly different from the amount of $\mathrm{N}$-total inoculation A1, F1, F2, S1, S2, C1, and C2. F2 increased availability of $P(20.79 \mathrm{ppm})$ in the soil higher than $\mathrm{KO}, \mathrm{Al}, \mathrm{F1}$; and not significantly different from $A 2, S 1, S 2, C 1$, and C2. KO treatment gave C/N ratio of soil significantly different from A1, A2, F1, F2, S1, S2, C1 and C2; BPS which showed activity in overhauling C-organic in the soil. Inoculation $A 2$ and $F 2$ increased plant height $15.48 \%$ and $9.31 \%$ higher than the control. Inoculation of $C 2$ differed significantly in improving the fresh weight compared to control; and not significantly different from A1, A2, F1, F2, S1, S2, and $C 1$ and able to increase the dry weight of $71.12 \%$ compared to the control.
\end{abstract}

Keywords: Azospirillum, Cellulolytic Bacteria, Phosphate Solubilizing Bacteria, Snake Fruit

\begin{abstract}
ABSTRAK
Salak Pondoh [Salacca zalacca (Gaertner) Voss] merupakan tanaman buah bernilai tinggi dan diminati masyarakat. Budidaya salak diawali dengan pembibitan. Penelitian ini bertujuan menguji pengaruh bakteri potensial hasil isolasi dan seleksi dari bakteri pelarut fosfat (BPF), bakteri perombak selulosa (BPS), dan bakteri pemfiksasi $\mathrm{N}_{2}$ (Azospirillum) dalam pertumbuhan bibit tanaman salak pondoh. Penelitian ini menggunakan rancangan acak lengkap satu faktor yang terdiri atas: K0 (tanpa inokulum/Kontrol); A1 (inokulum Azospirillum $5 \mathrm{ml}$ ), A2 (25 ml inokulum); F1 (inokulum BPF dosis $5 \mathrm{ml}$ ), F2 (dosis $25 \mathrm{ml}$ ); S1 (inokulum BPS dosis $5 \mathrm{ml}$ ), S2 (dosis $25 \mathrm{ml}$ ); C1 (inokulum campuran $\mathrm{A}+\mathrm{F}+\mathrm{S}$ dosis $5 \mathrm{ml}$ ), dan $\mathrm{C} 2$ (dosis $25 \mathrm{ml}$ ). Pengamatan dilakukan selama 10 minggu sampai bibit salak Pondoh memiliki dua daun. Hasil penelitian menunjukkan inokulasi A2 dan S2 nyata jumlah N-total (0.99\%) di dalam tanah dibandingkan dengan K0; tetapi tidak berbeda nyata dibandingkan dengan perlakuan lain. Inokulasi F2 nyata meningkatkan P tersedia (20.79 ppm) di dalam tanah dibandingkan dengan $\mathrm{K} 0, \mathrm{~A} 1, \mathrm{~F} 1$; dan tidak berbeda nyata dengan A2, S1, S2, C1, dan $\mathrm{C} 2$. Induksi dengan seluruh isolat nyata terhadap $\mathrm{C} / \mathrm{N}$ rasio tanah; yang menunjukkan adanya aktivitas BPS dalam merombak C-organik di dalam tanah. Inokulasi A2 dan F2 mampu meningkatkan tinggi tanaman $9.31 \%$ dan $15.48 \%$ lebih besar dibandingkan kontrol. Inokulasi C2 nyata meningkatkan bobot basah bibit salak pondoh dibandingkan kontrol; tetapi tidak berbeda nyata dengan perlakuan lain serta mampu meningkatkan bobot kering $71.12 \%$ dibandingkan kontrol.
\end{abstract}

Kata kunci: Azospirillum, bakteri pelarut fosfat, bakteri perombak selulosa, Salak Pondoh

${ }^{1}$ Departemen Manajemen Sumber Daya Lahan, Fakultas Pertanian, Institut Pertanian Bogor

(Bogor Agricultural University), Jl. Meranti, Kampus IPB Darmaga, Bogor 16680, Indonesia

*Email korespondensi: fhazra2011@yahoo.com 


\section{PENDAHULUAN}

Salak Pondoh merupakan salah satu jenis buah tropik asli Indonesia yang banyak diminati masyarakat karena rasanya manis dan memiliki nilai ekonomi. Menurut Gustini (2012), salak Pondoh dapat dikembangkan secara generatif dan vegetatif. Budidaya salak pondoh secara generatif memiliki keuntungan antara lain; dapat dikerjakan dengan mudah dan murah, diperoleh bibit yang banyak, tanaman yang dihasilkan tumbuh lebih sehat, tanaman yang dihasilkan memiliki perakaran kuat sehingga tahan rebah, dan kemungkinan diadakan perbaikan sifat dalam bentuk persilangan (Prihatman, 2000).

Faktor yang mempengaruhi pertumbuhan bibit salak pondoh adalah ketersediaan hara bagi tanaman. Unsur hara makro esensial yang dibutuhkan tanaman adalah unsur nitrogen $(\mathrm{N})$ dan fosfor (P), yang dapat ditambahkan ke dalam tanah dalam bentuk pupuk (Alinajati dan Mirshekari, 2011). Penggunaan pupuk kimia yang mengandung unsur $\mathrm{N}$ dan $\mathrm{P}$ secara berlebih akan menyebabkan kesuburan tanah semakin berkurang (Alam et al., 2009). Ketersediaan hara di dalam tanah belum tentu mencukupi kebutuhan hara tanaman. Salah satu cara untuk mengatasinya ialah menggunakan mikroorganisme asal tanah. Menurut Agus (1997), aktivitas mikroorganisme tanah mampu memperlancar siklus unsur hara dan menyuplai hormon serta enzim yang berguna bagi pertumbuhan tanaman dan mempengaruhi kesuburan tanah. Beberapa mikroorganisme tanah, seperti Azospirillum, bakteri pelarut fosfat (BPF), bakteri perombak selulosa (BPS) bila dimanfaatkan dengan baik akan membawa pengaruh baik bagi ketersediaan hara yang dibutuhkan tanaman.

Menurut Taurian et al. (2010), inokulasi bakteri pelarut fosfat terhadap tanaman mampu meningkatkan biomasa tanaman karena mampu menghasilkan hormon tanaman. Menurut Menzuan et al. (2002), kombinasi pupuk hayati dengan rata-rata terbaik pada formula B terdiri atas Azospirillum sp., Aspergillus sp., dan Streptomyces sp. yang ditambah bahan organik dapat mempengaruhi sifat fisik dan biologi tanah, khususnya stabilitas agregat dan bioaktivitas tanah. Maryanto dan Ismangil (2010) menyatakan penggunaan pupuk hayati dan batuan fosfat alam mampu meningkatkan ketersediaan $\mathrm{P}$ pada tanah Andisol, panjang tanaman, bobot tanaman kering dan bobot buah segar pada tanaman stroberi. Interaksi antara pupuk hayati dan batuan fosfat alam dapat meningkatkan $\mathrm{pH}$ tanah Andisol. Penelitian ini merupakan salah satu langkah penting dalam pemanfaatan mikroba lokal asal Jambi khususnya Azospirillum, bakteri pelarut fosfat, dan bakteri perombak selulosa sebagai bahan dasar pupuk hayati yang diaplikasikan terhadap pembibitan tanaman salak pondoh pondoh yang ditumbuhkan pada tanah Regosol.

Penelitian ini bertujuan untuk menguji pengaruh bakteri pelarut fosfat, bakteri perombak selulosa dan Azospirillum dalam meningkatkan pertumbuhan bibit tanaman salak Pondoh.

\section{BAHAN DAN METODE}

Bahan yang digunakan dalam penelitian ini adalah benih salak Pondoh, sampel tanah untuk isolasi bakteri berpotensi berasal dari Sungai Banir, Bangko Kuning dan Sepintun Provinsi Jambi, tanah regosol (Darmaga) untuk media pembibitan salak, media Nitrogen Free Bromtimol (NFB) untuk Azospirillum, media pikovskaya untuk BPF, media Carboxil Methyl Cellulose (CMC) 1\% untuk BPS, media Luria Bertani (LB), media Nutrient Agar (NA), Nutrient Broth (NB), Larutan Fisiologis (LF) $0.85 \% \mathrm{NaCl}$. Alat yang digunakan adalah peralatan gelas (cawan petri, Erlenmeyer, tabung reaksi), $\mathrm{pH}$ meter, paper disc, inkubator, ruang laminar, shaker, buret, alat Kjeldahl.

Sepuluh gram tanah dilarutkan dalam $90 \mathrm{ml}$ larutan fisiologis (larutan $\mathrm{NaCl} 0.85 \%$ ), kemudian diencerkan secara seri sampai tingkat pengenceran $10^{5}$. Satu $\mathrm{ml}$ suspensi yang diperoleh diisolasi dalam media Pikovskaya untuk isolasi BPF dan media CMC untuk isolasi BPS dari tingkat pengenceran $10^{3}$ hingga $10^{4}$ serta dalam media Nitrogen Free Bromtimol (NFB) semi padat untuk isolasi Azospirillum dari tingkat pengenceran $10^{3}$ hingga $10^{5}$. Inkubasi selama 3-5 hari untuk BPF dan BPS dalam inkubator dan Azospirillum diinkubasi selama selama tujuh hari dalam kondisi suhu ruangan. Setelah isolasi, kemudian dilakukan tahap pemurnian (purification) dan hasilnya dibuat stock culture. 
Seleksi Azospirillum dilakukan menggunakan metode Kjeldahl. Seleksi BPF dilakukan melalui uji kualitatif dilakukan dengan menumbuhkan isolat pada media pikovskaya menggunakan metode titik. Setelah masa inkubasi selama 3 hari berakhir, ditentukan diameter zona bening dan diameter koloni BPF diukur dan nilai Indeks Pelarutan (IP) ditentukan. Uji kuantitatif dilakukan dengan menguji BPF yang ditumbuhkan media pikovskaya cair untuk ditentukan kandungan $\mathrm{P}$ terlarut dengan metode Olsen (Mukhlis, 2007). Seleksi BPS dilakukan dengan menumbuhkan BPS dalam media CMC menggunakan metode titik. Setelah masa inkubasi selesai, kemudian dilakukan pewarnaan menggunakan indikator Congo Red (CR) $0.1 \%$ untuk memperjelas zona bening yang terbentuk. Setelah 15 menit, dibilas dengan $\mathrm{NaCl} 1$ M. Nilai indeks selulolitik BPS ditentukan.

Berdasarkan hasil seleksi, dipilih satu isolat terbaik Azospirillum, BPF, dan BPS. Isolat ditumbuhkan pada media LB selama 48 jam. Hasil biakan tersebut disebut sebagai larutan uji. Isolat digoreskan menggunakan cotton swab di media Nutrient Agar (NA), lalu paper disc dicelupkan ke larutan uji dan diletakkan di media agar dengan komposisi yang berbeda. Apabila ditumbuhkan di media NA dengan isolat Sepintun-2aP, 3 paper disc dicelupkan pada larutan uji yang mengandung Sepintun-4aA, Sepintun-1aS, lalu diinkubasi selama 48 jam. Reaksi positif ditunjukkan dengan terbentuknya zona bening di sekeliling paper disc.

Untuk mengetahui potensi patogenisitas bakteri dilakukan uji hipersensitivitas. Isolat terpilih dibiakkan dalam media LB selama 24 jam. Setelah masa inkubasi berakhir, dilakukan inokulasi pada daun tanaman tembakau menggunakan syringe tanpa jarum sebanyak $1 \mathrm{ml}$ tanpa meninggalkan luka pada daun tanaman. Pengamatan dilakukan 48 jam setelah inokulasi. Reaksi positif ditandai dengan timbulnya nekrosis pada daun.

Bakteri berpotensi hasil seleksi, kemudian diaplikasikan pada pembibitan salak pondoh. Penelitian ini menggunakan Rancangan Acak Lengkap dengan perlakuan: tanpa inokulasi/kontrol $\left(\mathrm{K}_{0}\right)$, diinokulasi Azospirillum $5 \mathrm{ml}\left(\mathrm{A}_{1}\right)$ dan $25 \mathrm{ml}\left(\mathrm{A}_{2}\right)$, diinokulasi BPF $5 \mathrm{ml}\left(\mathrm{F}_{1}\right)$, dan $25 \mathrm{ml}\left(\mathrm{F}_{2}\right)$, diinokulasi BPS $5 \mathrm{ml}\left(\mathrm{S}_{1}\right)$, dan $25 \mathrm{ml}\left(\mathrm{S}_{2}\right)$, diinokulasi campuran $\mathrm{A}+\mathrm{F}+\mathrm{S} 5 \mathrm{ml}\left(\mathrm{C}_{1}\right)$ dan 25 $\mathrm{ml}\left(\mathrm{C}_{2}\right)$.

Benih dikecambahkan terlebih dahulu. Perlakuan pembibitan diawali dengan melakukan perkecambahan benih yang dipilih dari biji buah dengan ukuran yang sama dan sehat, kemudian dibersihkan dari daging buah, dan dicuci bersih dengan air mengalir kemudian direndam selama 1 malam. Perendaman dilakukan untuk memecah dormansi benih. Setelah direndam, benih disimpan selama 45 hari di tempat gelap dan lembab di dalam plastik yang sudah dilubangi, atau hingga muncul akar dari biji. Benih salak pondoh yang sudah memiliki akar kemudian dimasukkan ke dalam polibag yang sudah berisi tanah steril \pm sebanyak $2 \mathrm{~kg}$ tanah kering udara.

Perhitungan total populasi Azospirillum, BPF, dan BPS dilakukan menggunakan Total Plate Count (TPC). Isolat bakteri ditumbuhkan dalam media Nutrient Broth (NB) dan diinkubasi selama 5 hari. Isolat NB dipipet sebanyak $1 \mathrm{ml}$ dan dimasukkan ke dalam $9 \mathrm{ml}$ larutan fisiologis secara aseptik dalam seri pengenceran sampai $10^{8}$. Suspensi dari pengenceran $10^{-5}, 10^{-6}, 10^{-7}, 10^{-8}$ dituangkan pada cawan petri yang berisi media Nutrient Agar (NA) untuk pengujian CFU Azospirillum, media pikovskaya untuk pengujian CFU BPF, dan media CMC untuk pengujian CFU BPS. Perhitungan dilakukan untuk mengetahui jumlah populasi mikroorganisme pada pupuk hayati yang akan diaplikasikan ke tanah.

Inokulasi dilakukan dengan cara menambahkan inokulum dengan kerapatan $10^{7}$ $\mathrm{CFU} / \mathrm{ml}$ untuk BPF dan BPS, sedangkan Azospirillum dengan kerapatan $10^{5} \mathrm{CFU} / \mathrm{ml} \mathrm{di}$ sekitar benih yang ditanam. Perbanyakan inokulum dilakukan sebelum benih yang dikecambahkan dipindahkan ke polibag. Sebelumnya sudah dilakukan pengukuran kandungan $\mathrm{P}$ tersedia, \%C-Organik, N-total tanah awal. Pengamatan dilakukan selama 10 minggu sampai bibit salak pondoh memiliki dua daun.

Analisis data hasil pengukuran nilai $\mathrm{P}$ tersedia, $\mathrm{N}$-total tanah, $\mathrm{C} / \mathrm{N}$ rasio tanah, dan serapan N, P tanaman menggunakan Analisis Ragam (ANOVA) dan uji lanjut dengan Duncan Multiple Range Test (DMRT) pada taraf $5 \%$. 


\section{HASIL DAN PEMBAHASAN}

\section{Isolasi dan Pemurnian Bakteri}

Berdasarkan hasil isolasi dari sampel tanah di Bangko Kuning, Sepintun, dan Sungai Banir diperoleh 40 isolat Azospirillum, 55 isolat BPF, dan 35 isolat BPS. Isolat tersebut dipilih berdasarkan pengelihatan secara visual terhadap pelikel yang terbentuk pada Azospirillum, zona bening yang terbentuk pada BPF dan BPS. Setelah proses isolasi bakteri dilakukan, tahapan selanjutnya adalah melakukan proses pemurnian. Pemurnian dilakukan pada bakteri pelarut fosfat, bakteri perombak selulosa, dan Azospirillum. Pemurnian dilakukan sebanyak 2-3 kali sampai diperoleh koloni tunggal sesuai yang diharapkan. Hasil proses pemurnian diperoleh 20 isolat Azospirillum, 22 isolat bakteri pelarut fosfat, dan 18 isolat bakteri perombak selulosa. Dari hasil pemurnian tersebut selanjutnya akan dilakukan seleksi sesuai dengan karakteristik bakteri.

\section{Uji Kemampuan Azospirillum Menambat Nitrogen}

Pengujian Azospirillum menggunakan metode Kjeldahl dilakukan untuk mengetahui jumlah $\mathrm{N}$ yang dapat ditambat oleh Azospirillum dalam biakan media Nitrogen Free Bromtimol (NFB) cair. Hasil pengujian Tabel 1 menunjukkan isolat yang ditumbuhkan dalam media cair NFB yang memiliki jumlah $\mathrm{N}$ tertinggi yaitu isolat SungaiBanir2-A dengan kadar Nitrogen $1.12 \%$, sedangkan isolat yang memiliki jumlah $\mathrm{N}$ terendah adalah isolat BangkoKuning9-A dengan kadar $\mathrm{N}$ $0.08 \%$. Jumlah nilai $\mathrm{N}$ yang ditambat oleh
Azospirillum dalam media NFB cair prinsipnya adalah mendegradasi bahan organik dengan menggunakan asam sulfat pekat untuk menghasilkan nitrogen sebagai ammonia, kemudian menghitung jumlah nitrogen yang terlepas sebagai ammonia lalu dikonversikan ke dalam kadar protein dengan mengalikannya dengan konstanta tersebut (Arief, 1989).

\section{Uji Kualitatif dan Uji Kuantitatif BPF}

Sebanyak 22 isolat bakteri pelarut fosfat (BPF) diperoleh dari hasil isolasi dan pemurnian. Uji kualitatif dilakukan dengan menentukan Indeks Pelarutan (IP) BPF. Indeks pelarutan merupakan perbandingan antara diameter zona bening dengan diameter koloni bakteri. Hasil uji kualitatif dan kuantitatif disajikan pada Tabel 2.

Isolat Sepintun2-aP mampu melarutkan fosfat dalam media pikovskaya agar paling tinggi dibandingkan dengan isolat lain. Hal itu ditunjukkan dengan nilai Indeks Pelarutan (IP) fosfat tertinggi yaitu sebesar 1.81, sedangkan isolat BangkoKuning1-P memiliki nilai IP fosfat terendah yaitu 0.82 (Tabel 2). Indeks pelarutan fosfat merupakan perbandingan antara diameter zona bening dengan diameter koloni bakteri. Zona bening (holozone) yang terbentuk di sekeliling koloni karena mikroba pelarut fosfat mampu mensekresikan asamasam organik yang dapat mengubah $\mathrm{P}$ yang tidak larut menjadi larut (Gonggo dan Yuni, 2006). Isolat Sepintun2-aP memiliki daya larut $\mathrm{P}$ dalam media pikovskaya cair yang tertinggi yaitu dengan P-larut 218.3 ppm P memiliki daya larut $\mathrm{P}$ terendah, sedangkan isolat BangkoKuning8-P dengan P-larut 9.7 ppm P.

Tabel 1. Hasil uji penambatan nitrogen dengan Metode Kjeldahl

\begin{tabular}{lclc}
\hline Kode Isolat & Kadar N $(\%)$ & Kode Isolat & Kadar N (\%) \\
\hline Sepintun1-A & 1.01 & BangkoKuning4-A & 0.28 \\
Sepintun2-A & 1.01 & BangkoKuning5-A & 0.98 \\
Sepintun2-aA & 0.11 & BangkoKuning6-A & 0.13 \\
Sepintun3-A & 0.07 & BangkoKuning8-A & 0.11 \\
Sepintun4-A & 1.10 & BangkoKuning9-A & 0.08 \\
Sepintun5-A & 0.24 & BangkoKuning-10A & 0.13 \\
Sepintun5-aA & 0.12 & SungaiBanir1-A & 1.08 \\
BangkoKuning1-A & 0.55 & SungaiBanir2-A & 1.12 \\
BangkoKuning2-A & 0.19 & SungaiBanir3-A & 1.09 \\
BangkoKuning3-A & 1.08 & SungaiBanir5-A & 1.05 \\
\hline
\end{tabular}


Tabel 2. Indeks pelarutan (IP) dan P-tersedia bakteri pelarut fosfat

\begin{tabular}{lcclcr}
\hline \multicolumn{1}{c}{ Kode Isolat } & IP & $\begin{array}{c}\text { P-Tersedia } \\
(\mathrm{ppm})\end{array}$ & \multicolumn{1}{c}{ Kode Isolat } & IP & $\begin{array}{c}\text { P-Tersedia } \\
(\mathrm{ppm})\end{array}$ \\
\hline Sepintun1-P & 1.45 & 47.8 & SungaiBanir4-P & 1.28 & 57.5 \\
Sepintun1-aP & 1.02 & 74.9 & SungaiBanir5-P & 1.55 & 27.1 \\
Sepintun2-aP & 1.81 & 218.3 & BangkoKuning1-P & 0.82 & 31.5 \\
Sepintun2-cP & 1.60 & 178.9 & BangkoKuning3-P & 1.22 & 56.5 \\
Sepintun3-P & 1.20 & 66.2 & BangkoKuning4-P & 1.21 & 52.1 \\
Sepintun4-P & 1.32 & 40.2 & BangkoKuning5-P & 1.17 & 140.1 \\
Sepintun5-P & 1.49 & 55.7 & BangkoKuning6-P & 1.50 & 51.8 \\
SungaiBanir1-dP & 1.05 & 139.6 & BangkoKuning7-P & 1.55 & 174.8 \\
SungaiBanir2-aP & 1.65 & 179.2 & BangkoKuning8-P & 1.42 & 9.7 \\
SungaiBanir3-P & 1.05 & 35.8 & BangkoKuning9-P & 1.05 & 71.7 \\
SungaiBanir3-aP & 1.07 & 91.7 & BangkoKuning10-P & 1.07 & 47.8 \\
\hline
\end{tabular}

Isolat yang memiliki nilai IP tinggi, tidak selalu berbanding lurus dengan kemampuan BPF melarutkan $P$ dalam media cair dan isolat yang memiliki daya larut $\mathrm{P}$ dalam media cair Pikovskaya rendah tidak selalu berbanding lurus dengan nilai IP, isolat BangkoKuning8-P sebagai salah satu contohnya. Isolat Bangko-Kuning8-P memiliki nilai P-larut yang terendah namun memiliki nilai IP sebesar 1.42 (Tabel 2).

\section{Uji Kemampuan BPS Merombak Selulosa}

Hasil isolasi dan pemurnian diperoleh 18 isolat bakteri yang mampu merombak selulosa. Seleksi BPS terbaik dilakukan dengan menguji BPS menggunakan media agar spesifik Carboxymethyl cellulose (CMC). Zona bening yang terbentuk dalam media CMC menunjukkan selulosa yang mampu dirombak oleh BPS. Hasil pengujian disajikan pada Tabel 3.

Isolat yang mampu mendegradasi selulosa ditandai dengan adanya zona bening di sekitar koloni dan diperjelas dengan menggunakan indikator Congo Red $0.1 \%$ kemudian ditentukan nilai indeks selulolitik dari BPS. Tabel 3 menunjukkan isolat yang memiliki nilai Indeks Selulolitik (IS) tertinggi adalah Sepintun1-aS yaitu 0.75, sedangkan isolat yang memiliki nilai IS terendah adalah Sepintun3-S yaitu 0.03 (Tabel 3). Indeks selulolitik yang berbeda menunjukkan bahwa isolat memiliki kemampuan menghasilkan selulase yang berbeda pula dalam menghidrolisis substrat CMC. Bakteri pendegradasi selulosa merupakan salah satu mikroorganisme pendegradasi bahan organik dan memiliki peranan penting dalam biosfir dengan mendaur-ulang selulosa (Leschine, 1995; Saraswati et al., 2006). Mikroorganisme jenis ini juga penting dalam beberapa proses fermentasi dalam industri, terutama dalam penghancuran limbah selulosa secara anaerob, sehingga menghasilkan lignoselulosa dengan persentase hingga 70\% (Cailliez et al., 1993).

Tabel 3. Indeks selulolitik (IS) bakteri perombak selulosa

\begin{tabular}{lclc}
\hline Kode Isolat & Indeks Selulolitik & Kode Isolat & Indeks Selulolitik \\
\hline Sepintun1-S & 0.27 & SungaiBanir3-ES & 0.25 \\
Sepintun1-aS & 0.75 & SungaiBanir4-S & 0.29 \\
Sepintun3-S & 0.03 & SungaiBanir5-eS & 1.00 \\
Sepintun5-S & 0.23 & BangkoKuning4-aS & 0.57 \\
SungaiBanir1-S & 0.14 & BangkoKuning4-bS & 0.33 \\
SungaiBanir2-S & 0.11 & BangkoKuning5-S & 0.07 \\
SungaiBanir2-eS & 0.10 & BangkoKuning6-S & 0.09 \\
SungaiBanir3-S & 0.19 & BangkoKuning8-S & 0.15 \\
SungaiBanir3-aS & 0.13 & BangkoKuning9-S & 0.14 \\
\hline
\end{tabular}


Berdasarkan seleksi terhadap BPF, BPS, dan Azospirillum untuk mendapatkan bakteri berpotensi diperoleh isolat terbaik untuk BPF dipilih berdasarkan nilai IP yang berbanding lurus dengan P-larut dengan nilai tertinggi adalah isolat Sepintun2-aP. Isolat BPS terbaik yang mampu merombak selulosa dengan nilai IS terbaik yaitu Sepintun1-aS. Isolat Azos-pirillum terbaik memiliki jumlah $\mathrm{N}$ tertinggi adalah isolat SungaiBanir2-A.

\section{Uji Antagonisme Bakteri}

Pengujian antagonis dilakukan dengan metode uji kombinasi dalam satu cawan petri menggunakan paper disc. Hasil uji antagonis secara in vitro disajikan pada Tabel 4.

Hasil pengujian menunjukkan bahwa isolat SungaiBanir5-eS bersifat antagonis terhadap isolat Sepintun2-aP yang ditunjukkan dengan terbentuknya zona bening di sekeliling paper disc. Namun, pada uji kebalikannya dengan isolat 1 adalah isolat SungaiBanir5-eS dan isolat 2 adalah Sepintun2-aP menunjukkan hasil negatif atau tidak menunjukkan adanya zona bening yang terlihat di sekeliling paper disc (Tabel 4). Sifat antagonis terlihat pada isolat SungaiBanir2-A terhadap isolat SungaiBanir5-eS, dan saat uji kebalikannya menunjukkan hasil negatif atau non-antagonis.

Tabel 4. Pengujian antagonis yang dikombinasikan secara in vitro

\begin{tabular}{lcc}
\hline \multicolumn{1}{c}{$\begin{array}{c}\text { Kode isolat } \\
\text { Isolat 1 vs Isolat 2 }\end{array}$} & \multicolumn{2}{c}{$\begin{array}{c}\text { Pengamatan } \\
\text { hari ke- }\end{array}$} \\
\cline { 2 - 3 } & 1 & 2 \\
\hline $\begin{array}{l}\text { Sepintun2-aP vs } \\
\text { SungaiBanir5-eS }\end{array}$ & + & + \\
$\begin{array}{l}\text { Sepintun2-aP vs } \\
\text { SungaiBanir2-A }\end{array}$ & - & - \\
$\begin{array}{l}\text { SungaiBanir5-eS vs } \\
\text { Sepintun2-aP }\end{array}$ & - & - \\
SungaiBanir5-eS vs & & \\
SungaiBanir2-A & + & + \\
$\begin{array}{l}\text { SungaiBanir2-A vs Sepintun2-aP } \\
\text { SungaiBanir2-A vs } \\
\text { SungaiBanir5-eS }\end{array}$ & - & - \\
\hline
\end{tabular}

\section{Uji Hipersensitivitas}

Hasil uji hipersensitivitas tiga isolat terpilih terhadap tanaman tembakau menunjukkan gejala negatif, karena tanaman tersebut tidak mengalami gejala klorosis ataupun nekrosis. Dengan demikian tiga isolat tersebut tidak bersifat patogen terhadap tanaman dan bisa digunakan sebagai pupuk hayati. Respon hipersensitif menurut Klement et al. (1990) diartikan sebagai reaksi pertahanan yang cepat dari tanaman menghadapi patogen yang disertai kematian sel yang cepat atau nekrosis jaringan di daerah yang diinjeksi dengan suspensi bakteri.

\section{Perhitungan Total Azospirillum, BPF, dan BPS}

Berdasarkan hasil uji menunjukkan pupuk hayati (inokulum cair) penambat $\mathrm{N}_{2}$ mengandung $2.5 \times 10^{7} \mathrm{CFU} / \mathrm{ml}$, bakteri pelarut fosfat mengandung $9.0 \times 10^{7}$, bakteri perombak selulosa mengandung $1.5 \times 10^{7}$ $\mathrm{CFU} / \mathrm{ml}$ (Tabel 5). Jumlah ini sesuai dengan yang tercantum dalam Permentan NOMOR 70/Permentan/SR.140/10/2011 mengenai standar pengujian bakteri hidup bebas.

\section{Pengujian terhadap Pertumbuhan Salak Pondoh}

Hasil penelitian menunjukkan adanya pengaruh inokulasi Azospirillum, BPF dan BPS terhadap pertumbuhan tanaman salak Pondoh. Hasil pengujian bakteri terhadap bibit salak Pondoh tersaji pada Tabel 6.

Bibit salak yang diinokulasi A1, A2, F1, F2, S1, S2, C1 dan C2 secara berturut- turut $9.70 \%, 9.31 \%, 18.7 \%, 15.48 \%, 8.87 \%, 17.64 \%$, $0.71 \%$ dan $9.70 \%$ lebih tinggi dibandingkan dengan yang tidak diinokulasi (kontrol). Berdasarkan hasil tersebut isolat F1 mampu meningkatkan tinggi bibit salak Pondoh lebih besar dibandingkan isolat lain meskipun tidak berbeda nyata secara statistika. Hal ini seperti yang dinyatakan oleh Havlin et al. (2005), unsur hara $\mathrm{P}$ diserap tanaman untuk pembelahan sel tanaman, sehingga menyebabkan meningkatnya tinggi tanaman. Menurut Ponmurugan dan Gopi (2006), mikroba pelarut fosfat dalam kegiatannya mampu mengeluarkan zat pengatur tumbuh (indole acetic acid dan gibberellic acid).

Tabel 5. Hasil uji total bakteri pada inokulum yang akan diberikan pada tanah.

\begin{tabular}{lc}
\hline \multicolumn{1}{c}{ Jenis Isolat } & Jumlah CFU/ml \\
\hline SungaiBanir2-A (A) & $2.5 \times 10^{5}$ \\
Sepintun2-aP (F) & $9.0 \times 10^{7}$ \\
SungaiBanir5-eS (S) & $1.5 \times 10^{7}$ \\
Campuran (C) & $9.5 \times 10^{7}$ \\
\hline
\end{tabular}


Tabel 6. Hasil analisis tanah dan tanaman setelah inokulasi bakteri

\begin{tabular}{lccclllll}
\hline Perlakuan & Tinggi & Tanaman & Bobot & Basah & Bobot & & \multicolumn{3}{c}{ Tanah } & \multicolumn{2}{c}{ Tering } \\
\cline { 7 - 9 } & $(\mathrm{cm})$ & $(\mathrm{g})$ & $(\mathrm{g})$ & $\% \mathrm{~N}$ & $\mathrm{P}(\mathrm{ppm})$ & $\mathrm{C} / \mathrm{N}$ & $\% \mathrm{~N}$ & $\mathrm{P}(\mathrm{ppm})$ \\
\hline Kontrol & $22.67 \mathrm{a}$ & $7.55 \mathrm{a}$ & $1.87 \mathrm{a}$ & $0.75 \mathrm{a}$ & $17.47 \mathrm{a}$ & $3.08 \mathrm{a}$ & $1.52 \mathrm{a}$ & $14.17 \mathrm{a}$ \\
$\mathrm{A} 1$ & $24.87 \mathrm{a}$ & $9.93 \mathrm{ab}$ & $3.00 \mathrm{a}$ & $0.91 \mathrm{abc}$ & $20.38 \mathrm{a}$ & $1.72 \mathrm{~b}$ & $1.74 \mathrm{a}$ & $18.04 \mathrm{a}$ \\
$\mathrm{A} 2$ & $24.78 \mathrm{a}$ & $9.78 \mathrm{ab}$ & $2.33 \mathrm{a}$ & $0.98 \mathrm{bc}$ & $25.76 \mathrm{ab}$ & $2.07 \mathrm{~b}$ & $2.05 \mathrm{a}$ & $18.36 \mathrm{a}$ \\
$\mathrm{F} 1$ & $26.92 \mathrm{a}$ & $10.15 \mathrm{ab}$ & $3.17 \mathrm{a}$ & $0.87 \mathrm{abc}$ & $21.28 \mathrm{a}$ & $1.68 \mathrm{~b}$ & $1.76 \mathrm{a}$ & $19.14 \mathrm{a}$ \\
$\mathrm{F} 2$ & $26.18 \mathrm{a}$ & $9.48 \mathrm{ab}$ & $2.48 \mathrm{a}$ & $0.88 \mathrm{abc}$ & $41.33 \mathrm{bc}$ & $1.68 \mathrm{~b}$ & $1.78 \mathrm{a}$ & $20.78 \mathrm{a}$ \\
$\mathrm{S} 1$ & $24.68 \mathrm{a}$ & $9.40 \mathrm{ab}$ & $2.37 \mathrm{a}$ & $0.87 \mathrm{abc}$ & $30.35 \mathrm{ab}$ & $1.94 \mathrm{~b}$ & $1.80 \mathrm{a}$ & $17.07 \mathrm{a}$ \\
$\mathrm{S} 2$ & $26.67 \mathrm{a}$ & $10.58 \mathrm{ab}$ & $2.65 \mathrm{a}$ & $0.98 \mathrm{c}$ & $27.33 \mathrm{ab}$ & $1.43 \mathrm{~b}$ & $1.99 \mathrm{a}$ & $18.15 \mathrm{a}$ \\
$\mathrm{C} 1$ & $22.83 \mathrm{a}$ & $8.68 \mathrm{ab}$ & $2.04 \mathrm{a}$ & $0.85 \mathrm{abc}$ & $32.14 \mathrm{ab}$ & $1.70 \mathrm{~b}$ & $1.70 \mathrm{a}$ & $16.91 \mathrm{a}$ \\
$\mathrm{C} 2$ & $24.87 \mathrm{a}$ & $10.61 \mathrm{~b}$ & $3.20 \mathrm{a}$ & $0.79 \mathrm{abc}$ & $58.02 \mathrm{c}$ & $1.75 \mathrm{~b}$ & $1.95 \mathrm{a}$ & $17.71 \mathrm{a}$ \\
\hline
\end{tabular}

Keterangan: Angka yang diikuti oleh huruf yang sama pada kolom yang sama tidak berbeda nyata berdasarkan uji Duncan pada taraf nyata $5 \%$. $\mathrm{A}_{1}=$ inokulum Azospirillum $5 \mathrm{ml}, \mathrm{A}_{2}=$ inokulum Azospirillum $25 \mathrm{ml}, \mathrm{F}_{1}=$ inokulum BPF $5 \mathrm{ml}, \mathrm{F}_{2}=$ inokulum BPF $25 \mathrm{ml}, \mathrm{S}_{1}=$ inokulum BPS $5 \mathrm{ml}, \mathrm{S}_{2}=$ inokulum BPS $25 \mathrm{ml}$, $\mathrm{C}_{1}=$ inokulum $\mathrm{A}+\mathrm{F}+\mathrm{S} 5 \mathrm{ml}, \mathrm{C}_{2}=$ inokulum $\mathrm{A}+\mathrm{F}+\mathrm{S} 25 \mathrm{ml}$.

Bobot basah bibit salak Pondoh setelah panen yang diinokulasi $\mathrm{C}_{2}$ nyata lebih tinggi dibandingkan kontrol, namun tidak berbeda nyata dengan yang diinokulasi A1, A2, F1, F2, S1, S2, dan C1. Perlakuan inokulasi C2 mampu meningkatkan bobot basah bibit tanaman salak Pondoh $40.53 \%$ lebih berat dibandingkan kontrol, sedangkan perlakuan A1, A2, F1, F2, S1, S2, dan C1 mampu meningkatkan $31.52 \%, \quad 29.54 \%, \quad 34.44 \%$, $25.56 \%, 24.50 \%, 40.13 \%, 14.97 \%$ bobot basah tanaman dibandingkan kontrol. Inokulasi C2 mampu meningkatkan bobot kering $71.12 \%$ lebih berat dibandingkan kontrol, sedangkan perlakuan A1, A2, F1, F2, S1, S2 dan C1 mampu meningkatkan $60.43 \%, 24.60 \%$, $69.52 \%, 32.62 \%, 26.74 \%, 41.71 \%, 9.09 \%$ bobot kering dibandingkan kontrol.

Hal ini diduga karena inokulasi campuran antara Azospirillum, BPF dan BPS yang diberikan dalam satu tanaman mampu bersinergi satu sama lain tanpa saling menjatuhkan. Hal ini dibuktikan dengan hasil uji antogonisme secara in vitro bersifat nonantagonis, yang artinya tiga bakteri tersebut dapat dijadikan sebagai rekomendasi pupuk hayati. Hal ini sejalan dengan Permentan (2011) yang menyatakan pupuk hayati umumnya mengandung bakteri penambat nitrogen, mikroba pendegradasi selulosa dan mikroba pelarut fosfat. Peningkatan bobot tanaman kering menurut Gonggo dan Yuni (2006), karena ketersediaan P dalam tanah meningkat, sehingga merangsang pertumbuhan perakaran tanaman, bobot bahan kering, bobot biji, mempercepat masa kematangan, serta meningkatkan daya tahan terhadap serangan oleh cendawan.

Pengaruh inokulasi bakteri nyata menurunkan $\mathrm{C} / \mathrm{N}$ rasio tanah tempat tumbuh bibit salak Pondoh dibandingkan dengan kontrol. Hal itu membuktikan bahwa bakteri perombak selulosa mampu mendegradasi selulosa dan mengubahnya menjadi sumber karbon bagi bakteri itu sendiri dan bakteri lain. Pengaruh inokulasi A2 dan S2 terhadap jumlah $\mathrm{N}$ nyata lebih besar dibandingkan dengan kontol namun tidak berbeda nyata dengan jumlah $\mathrm{N}$ pada inokulasi A1, F1, F2, S1, C1, dan C2. Perlakuan A2 secara nyata mampu meningkatkan jumlah $\mathrm{N}$ di dalam tanah $30.67 \%$ dibandingkan kontrol, sedangkan A1 mampu meningkatkan $21.81 \% \mathrm{~N}$ yang diserap tanaman dibandingkan kontrol. Inokulasi F2 nyata meningkatkan $\mathrm{P}$ tersedia di tanah $46.65 \%$ lebih besar dibandingkan kontrol, A1, F1, tetapi tidak berbeda nyata dengan A2, S1, S2, C1, dan C2. Menurut Ponmurugan dan Gopi (2006), mikroba pelarut fosfat dalam kegiatannya mengeluarkan asam organik dan enzim fosfatase yang dapat membantu pelarutan fosfat dalam tanah, diduga menjadi penyebab ketersediaan fosfat di dalam tanah meningkat.

\section{KESIMPULAN}

Inokulasi bakteri berpotensi yaitu Azospirillum, bakteri pelarut fosfat dan bakteri perombak selulosa mampu me-nurunkan $\mathrm{C} / \mathrm{N}$ di tanah. Inokulasi C2 secara nyata mampu 
meningkatkan bobot basah dan bobot kering bibit salak Pondoh. Inokulasi A2 secara nyata mampu meningkatkan $\mathrm{N}$-total di dalam tanah dibandingkan kontrol. Inokulasi F2 nyata meningkatkan $\mathrm{P}$ tersedia di dalam tanah dibandingkan kontrol. Inokulasi A2 dan F2 mampu meningkatkan tinggi tanaman $9.31 \%$ dan $15.48 \%$ dibandingkan kontrol.

\section{DAFTAR PUSTAKA}

Alam, M.M., M.H. Ali, A.K.M. Ruhul Amin, M. Hassanuzzaman. 2009. Yield attributes, yield and harvest index of three irrigated rice varities under different levels of phosphorus. Advance Biological Research. 3(3-4)132-139.(b).

Alinajati, S.S., B. Mirshekari. 2011. Effect of phosphorus fertilization and seed bio fertilization on harvest index and phoshorus use efficiency of wheat cultivars. J Food, Agri \& Enviro 9(2): 388-397.

Agus, C. 1997. Respirasi tanah pada lantai hutan mangium. Buletin Kehutanan. 2: 23-35.

Arief, A. 1989. Biologi Umum. L.S.W. Malang.

Gustini, D., S. Fatonah, Sujarwati. 2012. Pengaruh Rootone F dan pupuk Bayfolan terhadap pembentukan akar dan pertumbuhan anakan salak Pondoh (Salacca edulis Reinw). Biospecies. 5(1): 8-13.

Gonggo, H., I. Yuni. 2006. Peran pupuk N dan $\mathrm{P}$ terhadap serapan $\mathrm{N}$, efisiensi $\mathrm{N}$ dan hasil tanaman jahe di bawah tegakan tanaman karet. Jurnal Ilmu-Ilmu Pertanian Indonesia. 8(1): 61-68.

Havlin, J.L., J.D. Beaton, S.L. Tisdale, W.L. Nelson. 2005. Soil Fertility and Fertilizers, An Introduction to Nutrient Management. $7^{\text {th }}$ ed. Pearson Education, Inc., New Jersey.

Klement, Z., K. Rudolph, D.C. Sands. 1990. Methods in Phytobacteriology. Akademiai Kiodo. Bundapest.

Leschine, S.B. 1995. Cellulose degradation in anaerobic environments. Annu. Rev. Microbiol. 49: 39 9-426.
Ma'ashum, M., J. Soedarsono, E. Susilowati. 2003. Biologi Tanah. CPIU Pasca IAEUP. Jakarta.

Marista, E., S. Khotimah, R. Linda. 2013. Bakteri pelarut fosfat hasil Iisolasi dari tiga jenis tanah rizosfer tanaman pisang Nipah (Musa paradisiaca var. nipah) di Kota Singkawang. Jurnal Probiont. 2(2): 93-101.

Maryanto, J., Ismangil. (2010) Pengaruh pupuk hayati dan batuan fosfat alam terhadap ketersediaan fosfor dan pertumbuhan stroberi pada tanah andisol. J. Hort Indonesia. 1(2): 66-73.

Menzuan, I.P. Handayani, E. Inoriah. 2002. Penerapan formulasi pupuk hayati untuk budidaya padi gogo: studi rumah kaca. Jurnal Ilmu-Ilmu Pertanian Indonesia. 4(1): 27-34.

Mukhlis. 2007. Analisis Tanah Tanaman. USU Press. Medan.

Peraturan Menteri Pertanian Republik Indonesia No 70/Permentan/Sr.140/10/ 2011. 2011. Tentang Pupuk Organik, Pupuk Hayati, dan Pembenah Tanah.

Ponmurugan, P., C. Gopi. 2006. In vitro production of growth regulators and phosphatase activity by phosphate solubilizing bacteria. African J Biotech. 4: 348-350.

Prihatman, K. 2000. Salak Pondoh. http//: waritek.ristek.go.id/pertanian/salak pondoh.pdf. [18 September 2014].

Saraswati, R., R.D.M. Simanungkalit, D.A. Suriadikarta, D. Setyorini, W. Hartatik. 2006. Pupuk Organik Dan Pupuk Hayati: Organic Fertilizer and Biofertilizer. Balai Besar Penelitian dan Pengembangan Sumberdaya Lahan Pertanian, Bogor, Indonesia.

Taurian, T., M.S. Anzuay, J.G. Angelini, L.M. Tonelli, L. Luduena, D. Pena, F. Ibanez, A. Farba. 2010. Phosphate-solublizing peanut associated bacteria: screening for plant growth-promoting activities. Plant Soil. 329: 421-431. doi: 10.1007/s11104- 009-0168-x. 

J. Hort. Indonesia 6(1): 37-44. April 2015. 